\title{
Wolbachia distribution and cytoplasmic incompatibility based on a survey of 42 spider mite species (Acari: Tetranychidae) in Japan
}

\author{
T Gotoh ${ }^{1}, \mathrm{H}_{\text {Noda }}{ }^{2}$ and X-Y Hong ${ }^{1,3}$ \\ ${ }^{1}$ Laboratory of Applied Entomology and Zoology, Faculty of Agriculture, Ibaraki University, Ami, Ibaraki 300-0393, Japan; ${ }^{2}$ National \\ Institute of Agrobiological Sciences, Tsukuba, Ibaraki 305-8634, Japan; ${ }^{3}$ Department of Entomology, School of Plant Protection, Nanjing \\ Agricultural University, Nanjing, Jiangsu 210095, China
}

\begin{abstract}
Wolbachia are a group of maternally inherited bacteria that infect a wide range of arthropods. Wolbachia infections are known to result in the expression of various abnormal reproductive phenotypes, the best known being cytoplasmic incompatibility. The first systematic survey of 42 spider mite species in Japan revealed that seven species (16.7\%) were infected with Wolbachia. Wolbachia in the spider mites were grouped into three subgroups in supergroup B by phylogenetic analyses of the wsp gene. Most spider mites did not
\end{abstract}

show cytoplasmic incompatibility when infected males were crossed with uninfected females. However, all infected populations of Panonychus mori and Oligonychus gotohi (five and four populations, respectively) possessed modification-positive strains of Wolbachia, and the cytoplasmic incompatibility decreased egg hatchability and female ratio of the spider mites. Thus, some Wolbachia strains cause sex ratio distortion in their hosts.

Heredity (2003) 91, 208-216. doi:10.1038/sj.hdy.6800329

Keywords: Wolbachia; distribution; spider mite; cytoplasmic incompatibility

\section{Introduction}

Wolbachia are alpha proteobacteria that infect a wide range of arthropods (Werren et al, 1995a; Jeyaprakash and Hoy, 2000) and filarial nematodes (Bandi et al, 1998). Wolbachia infect at least $16.9 \%$ of neotropic insects (Werren et al, 1995a), and $19.3 \%$ of temperate insect species sampled in North America (Werren and Windsor, 2000). Wolbachia infection is very common in some insect groups. For instance, $50 \%$ of a sample of 50 Indonesian ant species (Wenseleers et al, 1998) and $28.1 \%$ of 89 wildcaught mosquito species in Southeast Asia (Kittayapong et al, 2000) are infected with Wolbachia. Other invertebrates besides insects are commonly infected with Wolbachia. A total of 22 out of $85(26 \%)$ species of isopod crustaceans (Bouchon et al, 1998) and nine of 10 species of filarial nematodes were found to be infected with Wolbachia (Bandi et al, 1998). However, none of the mollusk species tested were infected (Schilthuizen and Gittenberger, 1998). Wolbachia were subdivided into six supergroups from A to F (Lo et al, 2002) based on the ftsZ gene sequence (Werren et al, 1995b). Arthropods are mainly infected with Wolbachia belonging to supergroups $A$ and $B$, nematodes are infected with supergroups $C$ and $\mathrm{D}$, springtail is infected with supergroup E (Vandekerchove et al, 1999) and termites are infected with supergroup F (Lo et al, 2002).

Correspondence: T Gotoh, Laboratory of Applied Entomology and Zoology, Faculty of Agriculture, Ibaraki University, Ami, Ibaraki 300-0393, Japan. E-mail: gotoh@mx.ibaraki.ac.jp

Received 22 April 2003
In Acari (mites), Wolbachia have been detected in Metaseiulus occidentalis (Nesbitt) and Tetranychus urticae Koch (Johanowicz and Hoy, 1996), in a T. urticae strain from Athens (Tsagkarakou et al, 1996), and in six out of 16 species of spider mites and four out of 11 predatory mites (Breeuwer and Jacobs, 1996). These Wolbachia strains belong to the B-supergroup. However, not many species of Acari have been surveyed for Wolbachia.

Reproductive alterations by Wolbachia are known as cytoplasmic incompatibility, parthenogenesis, feminization and male-killing (O'Neill et al, 1997; Stouthamer et al, 1999). Among these phenomena, only cytoplasmic incompatibility is known in the spider mites. Breeuwer (1997) first reported cytoplasmic incompatibility in T. urticae and T. turkestani. The effect of Wolbachia on their host mites was then studied by several researchers (Breeuwer, 1997; Gomi et al, 1997; Perrot-Minnot and Norton, 1997; Johanowicz and Hoy, 1998, 1999; Gotoh et al, 1999a, b; Vala et al, 2000). The incompatibility cross in spider mites shows $\mathrm{F}_{1}$ zygotic mortality among females. Therefore, cytoplasmic incompatibility causes a reduced egg hatchability and a reduced female ratio. In contrast, three Wolbachia-infected species of Tetranychus did not show cytoplasmic incompatibility (Gomi et al, 1997; Gotoh et al, 1999a, b).

The aims of this study were to investigate the distribution of Wolbachia of the spider mites of Japan, to test the effects of Wolbachia on the reproductive traits of Japanese spider mites, and to determine the phylogenetic relationships of the different strains of Wolbachia. This is the first systematic survey of Wolbachia in spider mites. 


\section{Materials and methods}

\section{Spider mites collection and rearing}

A total of 42 of the 80 known species of spider mites in Japan were examined (Table 1; Ehara, 1999; Ehara and Yamaguchi, 2001; Ehara and Ohashi, 2002). Details of how these populations were collected are available at http://wwwa.agr.ibaraki.ac.jp/ shokubutu/gotoh/Cdata. pdf or from the author. The number of populations in each species used ranged from 1 to 75 . Mites were reared on detached common bean leaves (Phaseolus vulgaris) or, when available, the original host leaves in a climatecontrolled room $\left(25^{\circ} \mathrm{C}, \mathrm{L}: \mathrm{D}=16: 8, \mathrm{RH} 60 \%\right)$.

\section{PCR}

Two pairs of Wolbachia-specific primers were used to detect the presence of Wolbachia. One amplifies a part of the $f t s Z$ gene (Holden et al, 1993) and the other amplifies $16 S$ rDNA (O'Neill et al, 1992). PCR templates were made by homogenizing a single female adult in a $25-\mu 1$ mixture of STE buffer $(100 \mathrm{mM} \mathrm{NaCl}, 10 \mathrm{mM}$ Tris- $\mathrm{HCl}, 1 \mathrm{mM}$ EDTA, pH 8.0) with proteinase $\mathrm{K}(10 \mathrm{mg} / \mathrm{ml}, 2 \mu \mathrm{l})$. The

Table 1 Wolbachia infection in Japanese spider mites ${ }^{a}$

\begin{tabular}{|c|c|c|c|c|c|}
\hline $\begin{array}{l}\text { Genus } \\
\quad \text { Species }\end{array}$ & $\mathrm{N}^{\mathrm{b}}$ & $\begin{array}{c}\text { Volbachi } \\
(\%)\end{array}$ & $\begin{array}{l}\text { c Genus } \\
\text { Species }\end{array}$ & $\mathrm{N}^{\mathrm{b}}$ & $\begin{array}{c}\text { Wolbachiac } \\
(\%)\end{array}$ \\
\hline Aponychus & & & suginamensis & 1 & 0 \\
\hline corpuzae & 1 & 0 & tiliarium & 2 & 0 \\
\hline firmianae & 1 & 0 & uchidai & 1 & 0 \\
\hline Panonychus & & & uncatus & 2 & 0 \\
\hline bambusicola & 1 & 0 & Oligonychus & & \\
\hline citri & 72 & 0 & biharensis & 1 & 0 \\
\hline mori & 52 & 9.6 & coffeae & 1 & 0 \\
\hline osmanthi & 44 & 0 & formosanus & 1 & 0 \\
\hline thelytokus & 1 & 0 & gotohi (on Pasania) & 4 & 100.0 \\
\hline$u l m i$ & 2 & 0 & gotohi (on chestnut) & 2 & 50.0 \\
\hline Sasanychus & & & ilicis & 1 & 0 \\
\hline akitanus & 2 & 0 & Amphitetranychus & & \\
\hline Schizotetranychus & & & quercivorus & 2 & 0 \\
\hline bambusae & 1 & 0 & viennensis & 2 & 0 \\
\hline cercidiphylli & 2 & 100.0 & Tetranychus & & \\
\hline leguminosus & 2 & 0 & ezoensis & 1 & 0 \\
\hline longus & 3 & 0 & kanzawai & 75 & $29.3^{\mathrm{d}}$ \\
\hline recki & 1 & 0 & ludeni & 4 & 0 \\
\hline schizopus & 2 & 0 & neocaledonicus & 2 & 0 \\
\hline Yezonychus & & & parakanzawai & 16 & $31.3^{\mathrm{e}}$ \\
\hline sapporensis & 1 & 0 & phaselus & 1 & 0 \\
\hline Eotetranychus & & & piercei & 2 & 0 \\
\hline asiaticus & 1 & 0 & pueraricola & 38 & 47.4 \\
\hline cornicola & 1 & 0 & takafujii & 1 & 0 \\
\hline dissectus & 1 & 0 & urticae (green form) & 3 & $66.7^{f}$ \\
\hline rubricans & 1 & 0 & urticae (red form) & 6 & $0^{\mathrm{f}}$ \\
\hline smithi & 1 & 0 & & & \\
\hline
\end{tabular}

a Wolbachia were detected by PCR using the primers for $16 \mathrm{~S}$ rDNA (O'Neill et al, 1992) and the ftsZ gene (Holden et al, 1993). A total of 3-20 female adults were tested for each population. ${ }^{\mathrm{b}} \mathrm{Number}$ of populations tested. Percentage of the populations infected with

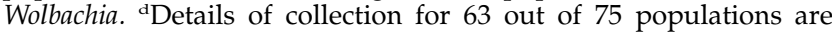
given in Gotoh et al (1999a; in this paper, T. kanzawai was referred to as the T strain of T. kanzawai). eDetails of collection for 11 out of 16 populations are given in Gotoh et al (1999a; in this paper, $T$. parakanzawai was referred to as the $\mathrm{K}$ strain of T. kanzawai). ${ }^{\mathrm{f}}$ Details of collection for two out of three populations of the green form of $T$. urticae and one out of six populations of the red form of T. urticae are given in Gotoh et al (1999b). mixture was incubated at $37^{\circ} \mathrm{C}$ for $30 \mathrm{~min}$ and proteinase $\mathrm{K}$ was inactivated at $95^{\circ} \mathrm{C}$ for $5 \mathrm{~min}$. The sample was briefly centrifuged in a microfuge tube, and used immediately for the PCR reaction or stored at $-20^{\circ} \mathrm{C}$ for later use. All PCR reactions were run in $26.25 \mu \mathrm{l}$ of buffer: $16 \mu \mathrm{H}_{2} \mathrm{O}, 2.5 \mu \mathrm{l} 10 \times$ buffer, $1.5 \mu \mathrm{l}$ dNTP $(2.5 \mathrm{mM}$ each $)$ $0.25 \mu \mathrm{l}$ Taq polymerase ( $1.25 \mathrm{U}$, TaKaRa rTaq, Tokyo), $2 \mu \mathrm{l}$ sample and $2 \mu \mathrm{l}$ of primers ( $20 \mathrm{pmol}$ each). Reactions were cycled 40 times for $30 \mathrm{~s}$ at $95^{\circ} \mathrm{C}$, for $30 \mathrm{~s}$ at $52^{\circ} \mathrm{C}$ and for $2 \mathrm{~min}$ at $72^{\circ} \mathrm{C}$. The techniques used here were the same as those used by Gomi et al (1997).

\section{Sequencing and phylogenetic analysis}

The phylogenetic relationship of Wolbachia in spider mites was based on the nucleotide sequence of the wsp gene. The wsp gene was amplified by $81 \mathrm{~F}$ and 691R primers (Zhou et al, 1998). The PCR product was cloned into a pGEM-T Vector (Promega). The template DNA was amplified by PCR using M13-20 and reverse primers. The sequence was determined by the Dye Terminator Sequencing method with a DNA Sequencer (model 377 and 3700, PE Applied Biosystems).

The wsp sequences were aligned with the CLUSTAL $X$ program (Thompson et al, 1997). Two parts of the variable region were removed and a data set of 494 nucleotide sites was used for the phylogenetic study. A neighbor-joining analysis was performed with CLUSTAL $X$ and a maximum-parsimony analysis was performed based on a heuristic search using PAUP v. 4.0b10 (Swofford, 1999). A bootstrap analysis was performed with 1000 replications.

\section{Cross experiments}

Two series of intraspecies crosses were carried out to determine the effects of Wolbachia on the reproduction of their hosts. One series of crosses was between a Wolbachia-infected population and a Wolbachia-uninfected population. The other series of crosses was between a Wolbachia-infected population and a Wolbachia-infected population that had been cured with antibiotic treatment. Tetracycline was administered to spider mites through the leaves by dissolving it in the water used to moisten the cotton bet under the leaves (Gotoh et al, 1995; Gomi et al, 1997). Rifampicin was also used for eliminating Wolbachia from Panonychus mori. The number of eggs laid by females during the first 5 days of oviposition was counted. We designated a crossing pair by the female/male population names. For example, Ami/Tsukuba indicates a cross between an Ami female and a Tsukuba male. In this paper, ' $\mathrm{W}^{-} / \mathrm{W}^{+}$' means a cross between a Wolbachia uninfected female and an infected male. Antibiotic-cured colonies are designated as ' $\mathrm{W}=$.'

Females in the teleiochrysalis stage (the final immature stage) obtained from each stock culture were transferred onto a small leaf disc ( $\mathrm{ca} 4 \mathrm{~cm}^{2}$ ) with a male adult (1- to 5day-old) either from the same or a different culture. Males were removed 2 days after adult emergence of the females. After oviposition started, each female was allowed to lay eggs for 5 days and then removed: that is, young mites were used. Eggs on leaf discs were checked daily to determine the hatchability, survival rate and sex ratio (\% females). All experiments were carried out at $25^{\circ} \mathrm{C}$ and $\mathrm{L}: \mathrm{D}=16: 8$. 


\section{Results}

Distribution of Wolbachia among mite species

We detected Wolbachia in seven (16.7\%) of the 42 mite species surveyed (Table 1). The seven species were members of the genera Panonychus, Shizotetranychus, Oligonychus and Tetranychus. Wolbachia have not yet been found in the genera Aponychus, Sasanychus, Yezonychus, Eotetranychus or Amphitetranychus.

Five out of 52 populations of $P$. mori were infected with Wolbachia. However, Wolbachia were not found in 72 populations of $P$. citri or in 44 populations of $P$. osmanthi. Two populations in Schizotetranychus cercidiphylli possessed Wolbachia. Both the chestnut and Pasania populations of Oligonychus gotohi were infected with Wolbachia. The infection frequencies of two closely related species, T. kanzawai and T. parakanzawai, were similar (29.3 and $31.3 \%$, respectively). Previously, 14 out of 63 populations of T. kanzawai and four out of 11 populations of T. parakanzawai were found to be infected with Wolbachia (Gotoh et al, 1999a; in this paper, T. kanzawai and T. parakanzawai were referred to as the $\mathrm{T}$ and $\mathrm{K}$ strains of T. kanzawai, respectively). In the present study, we included an additional eight infected populations of T. kanzawai and one additional infected population of T. parakanzawai. We detected Wolbachia in two of three populations of the green form of T. urticae, one of which was reported previously (Gotoh et al, 1999b). On the contrary, we failed to detect Wolbachia in six populations of the red form of T. urticae. Out of 38 populations of T. pueraricola, which morphologically resembles T. urticae, 18 were infected with Wolbachia. Thus, 59 (16.3\%) of the 362 populations examined were infected with Wolbachia.

\section{Wolbachia effects on spider mites}

We carried out crossing experiments and observed the effects of Wolbachia infection on egg hatchability, survival rate and sex ratio in all but one Wolbachia-infected species. The exception was $S$. cercidiphylli, which did not complete development because leaf discs of its host plant, Cercidiphyllum japonicum, swiftly deteriorated as a result of the tetracycline treatment. Two mite species, P. mori and O. gotohi (on Pasania), showed cytoplasmic incompatibility and four Tetranychus species did not show any reproductive abnormalities.

Effects on P. mori: Wolbachia-infected Toyama populations of $P$. mori showed unidirectional cytoplasmic incompatibility when females cured with rifampicin were crossed with infected males $\left(\mathrm{To}^{=} / \mathrm{To}^{+}\right)$(Table 2). The hatchability was quite normal, but cytoplasmic incompatibility was revealed by the male-biased sex ratio of the offspring. The Toyama population was infected with a modification-positive strain (CIWolbachia). Incompatibility was also observed in intrapopulation crosses between infected males and antibiotic-treated females in three other populations, Hanayama, Tsuruoka and Haruno, but not in the Sendai population (data not shown). Some local populations were also crossed, but the results were not simple. The spider mites had, in addition to Wolbachia-mediated CI, some inherent reproductive incompatibilities that appear to affect the reproductive biology among the populations (unpublished data).
Table 2 Compatibility of crosses between Wolbachia-infected $\left(\mathrm{To}^{+}\right)$ and antibiotic-treated $\left(\mathrm{To}^{-}\right)$colonies of the Toyama population of Panonychus mori

\begin{tabular}{ccccc}
\hline Cross & $\mathrm{N}^{\mathrm{a}}$ & $\begin{array}{c}\text { No. of } \\
\text { eggs/ } \\
\text { female }\end{array}$ & $\begin{array}{c}\text { Hatchability Survival rate } \\
(\%)\end{array}$ & $\begin{array}{c}\text { S Female } \\
\text { in immature } \\
\text { stages (\%) }\end{array}$ \\
\hline Female $\times$ Male & & & offspring
\end{tabular}

\begin{tabular}{llllllll}
\hline $\mathrm{To}^{+}$ & $\times \mathrm{To}^{+}$ & 15 & $32.0 \pm 0.95$ & $97.9 \pm 0.50$ & $97.8 \pm 0.63$ & $81.6 \pm 4.88 \mathrm{c}$ \\
$\mathrm{To}^{+}$ & $\times \mathrm{To}^{=}$ & 24 & $32.6 \pm 1.40$ & $96.8 \pm 0.52$ & $96.5 \pm 0.68$ & $71.9 \pm 1.03 \mathrm{~b}$ \\
$\mathrm{To}^{=}$ & $\times \mathrm{To}^{+}$ & 15 & $30.3 \pm 1.60$ & $96.5 \pm 0.35$ & $98.8 \pm 0.59$ & $25.5 \pm 1.39 \mathrm{a}$ \\
$\mathrm{To}^{=}$ & $\times$ & $\mathrm{To}^{=}$ & 24 & $34.0 \pm 1.28$ & $98.8 \pm 0.42$ & $97.4 \pm 0.55$ & $72.2 \pm 0.94 \mathrm{~b}$ \\
$\chi^{2}$-value & & & $5.508 \mathrm{~ns}$ & $6.431 \mathrm{~ns}$ & $4.128 \mathrm{~ns}$ & $50.842^{\text {b** }}$ \\
\hline
\end{tabular}

${ }^{a}$ Number of females tested. ${ }^{b}$ Means $( \pm S E)$ differ significantly at $P<0.001$ ( $\left.^{* * *}\right)$ (Kruskal-Wallis test); ns, not significant at $P>0.05$. The data of $\%$ female offspring followed by different letters are significantly different at $P<0.05$ (Scheffé's test). Arcsin-transformed values were used for analyzing the percentages of egg hatchability, survival rate and \% female offspring.

Effects on O. gotohi from Pasania: The populations of O. gotohi collected from Pasania, at four different locations, Futtsu $\left(\mathrm{Fu}^{+}\right)$, Kasumigaura $\left(\mathrm{Ka}^{+}\right)$, Ami $\left(\mathrm{Am}^{+}\right)$ and Hasaki $\left(\mathrm{Ha}^{+}\right)$, were all infected with Wolbachia. Therefore, members from the infected original populations were crossed with antibiotic-cured colonies (Table 3). We observed unidirectional cytoplasmic incompatibility between tetracycline-treated females and infected males. A male-biased sex ratio was observed in all incompatible crosses, $\mathrm{Fu}^{=} / \mathrm{Fu}^{+}, \mathrm{Fu}=/$ $\mathrm{Ka}^{+}, \mathrm{Fu}=/ \mathrm{Am}^{+}$and $\mathrm{Fu}=/ \mathrm{Ha}^{+}$, and significantly reduced hatchability in the former three crosses. On the other hand, crosses among four Wolbachia-infected populations $\left(\mathrm{Ka}^{+} / \mathrm{Fu}^{+}, \mathrm{Fu}^{+} / \mathrm{Ka}^{+}, \mathrm{Fu}^{+} / \mathrm{Am}^{+}\right.$and $\left.\mathrm{Fu}^{+} / \mathrm{Ha}^{+}\right)$did not cause any cytoplasmic incompatibility, indicating that the Wolbachia infecting these mites were the same strain.

Effects on $O$. gotohi from chestnut: In contrast, $O$. gotohi collected from chestnuts did not show cytoplasmic incompatibility. Two populations, one infected (Ami, $\mathrm{Am}^{+}$) and the other uninfected (Tsukuba, $\mathrm{Ts}^{-}$), were crossed, but no difference was found in the number of eggs, hatchability, survival rate in immature stages or female ratio among four crosses: $\mathrm{Am}^{+} / \mathrm{Am}^{+}, \mathrm{Ami}^{+} / \mathrm{Ts}^{-}$, $\mathrm{Ts}^{-} / \mathrm{Am}^{+}$, and $\mathrm{Ts}^{-} / \mathrm{Ts}^{-}$(Table 4). As $O$. gotohi on chestnuts was reproductively isolated from the same species on Pasania (Gotoh, unpublished data), populations from different host plants were not crossed.

Effects on T. kanzawai: For T. kanzawai, we previously reported that Wolbachia strains from 14 populations in Japan were all modification-negative or did not cause CI (Gomi et al, 1997; Gotoh et al, 1999a; in these papers, T. kanzawai was referred to as the T strain of T. kanzawai). This time, we tested another eight Wolbachia-infected strains: Tsukuba, Kimitsu, Haibara, Miza, Takeyano, Shidoshi, Sumiyoshi and Miyanoura. The males of the eight Wolbachia-infected populations of T. kanzawai were crossed with females of either the Wolbachia-infected population $\left(\mathrm{Ka}^{+}\right)$or the tetracycline-treated Kanaya population $\left(\mathrm{Ka}^{-}\right)$to clarify whether the Wolbachia strains infecting these populations are modificationpositive or -negative. The cross between $\mathrm{Ka}=$ females 
Table 3 Compatibility in crosses among Wolbachia-infected populations $\left(\mathrm{Fu}^{+}, \mathrm{Ka}^{+}, \mathrm{Am}^{+}\right.$or $\left.\mathrm{Ha}^{+}\right)$and tetracycline-treated Futtsu population $\left(\mathrm{Fu}^{=}\right)$of Oligonychus gotohi on Pasania

\begin{tabular}{|c|c|c|c|c|c|c|c|}
\hline \multicolumn{3}{|c|}{ Cross $^{\mathrm{a}}$} & \multirow[t]{2}{*}{$\mathrm{N}^{\mathrm{b}}$} & \multirow[t]{2}{*}{ No. of eggs/female } & \multirow[t]{2}{*}{ Hatchability (\%) } & \multirow[t]{2}{*}{ Survival rate in immatures (\%) } & \multirow[t]{2}{*}{$\%$ Female offspring } \\
\hline Female & $\times$ & Male & & & & & \\
\hline $\mathrm{Fu}^{+}$ & $\times$ & $\mathrm{Fu}^{+}$ & 15 & $13.9 \pm 0.71 \mathrm{a}$ & $96.0 \pm 1.66 \mathrm{a}$ & $86.1 \pm 1.93$ & $74.7 \pm 2.46 \mathrm{a}$ \\
\hline $\mathrm{Fu}^{+}$ & $x$ & $\mathrm{Fu}^{=}$ & 16 & $12.9 \pm 0.52 \mathrm{a}$ & $92.6 \pm 1.70 \mathrm{a}$ & $81.0 \pm 1.93$ & $74.0 \pm 1.96 \mathrm{a}$ \\
\hline $\mathrm{Fu}^{=}$ & $\times$ & $\mathrm{Fu}^{+}$ & 19 & $14.3 \pm 0.56 \mathrm{a}$ & $59.6 \pm 3.51 c$ & $87.4 \pm 2.13$ & $27.7 \pm 5.38 \mathrm{~b}$ \\
\hline $\mathrm{Fu}=$ & $x$ & $\mathrm{Fu}^{=}$ & 17 & $13.7 \pm 0.49 \mathrm{a}$ & $96.5 \pm 1.27 \mathrm{a}$ & $81.7 \pm 2.10$ & $70.3 \pm 1.60 \mathrm{a}$ \\
\hline $\mathrm{Ka}^{+}$ & $\times$ & $\mathrm{Ka}^{+}$ & 19 & $15.0 \pm 0.67 \mathrm{a}$ & $97.2 \pm 0.85 \mathrm{a}$ & $85.6 \pm 2.08$ & $74.7 \pm 1.45 \mathrm{a}$ \\
\hline $\mathrm{Ka}^{+}$ & $x$ & $\mathrm{Fu}^{+}$ & 14 & $15.4 \pm 0.66 \mathrm{a}$ & $94.9 \pm 1.87 \mathrm{a}$ & $85.7 \pm 2.55$ & $74.6 \pm 2.38 \mathrm{a}$ \\
\hline $\mathrm{Fu}^{+}$ & $\times$ & $\mathrm{Ka}^{+}$ & 14 & $13.6 \pm 0.57 \mathrm{a}$ & $91.8 \pm 1.95 \mathrm{a}$ & $85.0 \pm 2.77$ & $73.1 \pm 1.90 \mathrm{a}$ \\
\hline $\mathrm{Ka}^{+}$ & $x$ & $\mathrm{Fu}=$ & 18 & $13.7 \pm 0.65 \mathrm{a}$ & $96.6 \pm 1.29 \mathrm{a}$ & $91.8 \pm 1.95$ & $72.2 \pm 1.67 \mathrm{a}$ \\
\hline $\mathrm{Fu}=$ & $x$ & $\mathrm{Ka}^{+}$ & 17 & $12.1 \pm 0.59 \mathrm{a}$ & $56.4 \pm 5.03 \mathrm{c}$ & $85.8 \pm 3.07$ & $33.8 \pm 4.68 \mathrm{~b}$ \\
\hline $\mathrm{Fu}^{+}$ & $\times$ & $\mathrm{Am}^{+}$ & 13 & $12.9 \pm 0.58 \mathrm{a}$ & $93.0 \pm 2.19 \mathrm{a}$ & $82.1 \pm 2.48$ & $72.3 \pm 1.51 \mathrm{a}$ \\
\hline $\mathrm{Fu}^{=}$ & $x$ & $\mathrm{Am}^{+}$ & 15 & $13.1 \pm 0.61 \mathrm{a}$ & $64.6 \pm 5.82 \mathrm{c}$ & $84.2 \pm 2.59$ & $35.6 \pm 6.79 \mathrm{~b}$ \\
\hline $\mathrm{Fu}^{+}$ & $\times$ & $\mathrm{Ha}^{+}$ & 15 & $13.0 \pm 0.60 \mathrm{a}$ & $89.4 \pm 2.59 \mathrm{ab}$ & $87.5 \pm 2.17$ & $72.6 \pm 1.74 \mathrm{a}$ \\
\hline $\mathrm{Fu}^{=}$ & $\times$ & $\mathrm{Ha}^{+}$ & 15 & $11.9 \pm 0.47 \mathrm{a}$ & $71.8 \pm 3.81 \mathrm{bc}$ & $84.3 \pm 2.60$ & $45.8 \pm 5.81 \mathrm{~b}$ \\
\hline$\chi^{2}$-valve & & & & $26.231^{*}$ & $120.731^{* * *}$ & $11.229 \mathrm{~ns}$ & $127.010^{* * *}$ \\
\hline
\end{tabular}

${ }^{a}$ Fu: Futtsu, Chiba; Ka: Kasumigaura, Ibaraki; Am: Ami, Ibaraki; Ha: Hasaki, Ibaraki. ${ }^{b}$ Number of females tested. ${ }^{\mathrm{c}} \mathrm{Means}( \pm \mathrm{SE})$ differ significantly at $P<0.001{ }^{* * *}$ ) and $P<0.05\left(^{*}\right)$ (Kruskal-Wallis test); ns: not significant at $P>0.05$. Values in a column followed by different letters are significantly different at $P<0.05$ (Scheffé's test).

Table 4 Compatibility of crosses between the Wolbachia-infected Ami population $\left(\mathrm{Am}^{+}\right)$and the Wolbachia-uninfected Tsukuba population $\left(\mathrm{Ts}^{-}\right)$in Oligonychus gotohi on chestnut

\begin{tabular}{cccccc}
\hline Cross $^{\mathrm{a}}$ & $\mathrm{N}^{\mathrm{b}}$ & $\begin{array}{c}\text { No. of } \\
\text { eggs/ } \\
\text { females }\end{array}$ & $\begin{array}{c}\text { Hatchability } \\
(\%)\end{array}$ & $\begin{array}{c}\text { Survival } \\
\text { rate in } \\
\text { immatures (\%) }\end{array}$ & $\begin{array}{c}\% \text { Female } \\
\text { offspring }\end{array}$
\end{tabular}

Female $\times$ Male

\begin{tabular}{|c|c|c|c|c|c|c|}
\hline $\mathrm{Am}^{+}$ & $x$ & $\mathrm{Am}^{+}$ & $1526.4 \pm 0.86$ & $96.8 \pm 0.84$ & $96.0 \pm 1.06$ & $76.9 \pm 1.7$ \\
\hline $\mathrm{Ts}^{-}$ & $x$ & $\mathrm{Ts}^{-}$ & $1726.4 \pm 0.56$ & $96.4 \pm 0.67$ & $96.4 \pm 0.99$ & $79.3 \pm 1$ \\
\hline $\mathrm{Am}^{+}$ & $x$ & $\mathrm{Ts}^{-}$ & $2125.1 \pm 0.61$ & $96.5 \pm 0.78$ & $94.8 \pm 1.16$ & $75.3 \pm 1$. \\
\hline $\mathrm{Ts}^{-}$ & $x$ & $\mathrm{Am}^{+}$ & $1526.0 \pm 0.91$ & $96.7 \pm 0.70$ & $94.0 \pm 1.21$ & $75.5 \pm$ \\
\hline \multicolumn{3}{|c|}{$\chi^{2}$-value ${ }^{c}$} & $3.142 \mathrm{~ns}$ & $0.926 \mathrm{~ns}$ & $2.199 \mathrm{~ns}$ & $3.110 \mathrm{r}$ \\
\hline
\end{tabular}

aAm: Ami, Ibaraki; Ts: Tsukuba, Ibaraki. ${ }^{\circ}$ Number of females tested. cMeans $( \pm$ SE) are not significantly different at $P>0.05$ (KruskalWallis test); ns: not significant.

and the infected males of the test population did not result in an egg hatchability or sex ratio that was significantly different from those obtained from a cross between $\mathrm{Ka}^{+}$females and the infected males (Table 5).

Effects on $T$. parakanzawai: Four populations of T. parakanzawai were previously found to harbor a modification-negative strain of Wolbachia (Gotoh et al, 1999a; in this paper, T. parakanzawai was referred to as the K strain of T. kanzawai). The Wolbachia-infected Futtsu population of T. parakanzawai was newly examined here. Mites of the Futtsu population $\left(\mathrm{Fu}^{+}\right)$were crossed with those of the Wolbachia-free Ami $\left(\mathrm{Am}^{-}\right)$population, and hatchability and the sex ratio of the next generation were compared among the four crosses (Table 6). No significant differences were found in the crosses, indicating that Wolbachia in T. parakanzawai did not have cytoplasmic incompatibility.

Effects on $T$. pueraricola: A total of 18 Wolbachiainfected populations of $T$. pueraricola were crossed with the Wolbachia-free Ohta population. Reciprocal crosses between females of the test population and Ohta males and between Ohta females and males of the test population were similar with respect to hatchability, survival rate in immature stages and female ratios (Figure 1). Thus, the reciprocal crosses produced essentially the same results with some exceptions. When Wolbachia-free Ohta males were mated with Namerikawa $(\mathrm{Nm})$, Ikaruga (Ik) or Ube (Ub) females, the female ratio was significantly lower and Ikaruga females did not produce any females by mating with Ohta males (Figure 1). Although a reduced sex ratio resulted from these crosses, it did not appear to be due to Wolbachia-induced CI. Similar results were obtained from crosses using antibiotic-treated females, suggesting that there is a nucleus-to-nucleus incompatibility in these mating combinations (unpublished observation). For example, the cross between tetracycline-treated Ik females and Ohta males produced no female offspring with normal values in hatchability $(97.4 \pm 0.50$ (SE), $n=13)$ and survival rate $(94.2 \pm 0.94)$.

Effects on T. urticae: One Wolbachia-infected population in the green form of $T$. urticae (Kitsuregawa population) was found to harbor a modification-negative Wolbachia (Gotoh et al, 1999b). In another population (Yasato, $\mathrm{Ya}^{+}$), a Wolbachia-free colony was established by tetracycline treatment, and four combinations of crosses were observed between Wolbachia-infected and -free colonies. No differences were observed in hatchability, survival rate in immature stages or sex ratio among the four crosses (Table 7). As was observed to be the case in the Kitsuregawa population, Wolbachia in the Yasato population did not cause $\mathrm{CI}$.

\section{Phylogenetic relationships}

Nucleotide sequences of wsp genes of Wolbachia were determined for 21 mite populations (five P. mori populations, two $S$. cercidiphylli populations, two $O$. gotohi populations, four T. kanzawai populations, two T. para- 
Table 5 Compatibility of crosses between males of each Wolbachia-infected local population and females of either Wolbachia-infected Kanaya population $\left(\mathrm{Ka}^{+}\right)$or tetracycline-treated Kanaya population $\left(\mathrm{Ka}^{-}\right)$in Tetranychus kanzawai

\begin{tabular}{|c|c|c|c|c|c|c|c|c|c|c|c|}
\hline \multicolumn{3}{|c|}{ Cross $^{a}$} & \multirow[t]{2}{*}{$\mathrm{N}^{\mathrm{b}}$} & \multirow[t]{2}{*}{ No. of eggs/females ${ }^{c}$} & & \multirow[t]{2}{*}{ Hatchability $(\%)^{c}$} & & \multirow[t]{2}{*}{ Survival rate in immatures $(\%)^{c}$} & & \multirow[t]{2}{*}{$\%$ Female offspring ${ }^{c}$} & \\
\hline Female & $\times$ & Male & & & & & & & & & \\
\hline $\mathrm{Ka}^{+}$ & $\times$ & $\mathrm{Ts}^{+}$ & 12 & $25.5 \pm 2.37$ & $* *$ & $96.0 \pm 0.93$ & & $96.2 \pm 0.90$ & & $82.3 \pm 1.07$ & $*$ \\
\hline $\mathrm{Ka}^{=}$ & $\times$ & $\mathrm{Ts}^{+}$ & 9 & $36.7 \pm 2.72$ & & $96.2 \pm 1.04$ & ns & $99.1 \pm 1.17$ & ns & $86.8 \pm 1.10$ & \\
\hline $\mathrm{Ka}^{+}$ & $\times$ & $\mathrm{Ki}^{+}$ & 10 & $26.6 \pm 2.71$ & $* * *$ & $97.3 \pm 0.70$ & & $96.8 \pm 0.88$ & $*$ & $81.6 \pm 1.44$ & \\
\hline $\mathrm{Ka}=$ & $x$ & $\mathrm{Ki}^{+}$ & 12 & $45.1 \pm 1.98$ & & $96.8 \pm 0.72$ & 115 & $98.9 \pm 0.34$ & & $81.2 \pm 1.38$ & 115 \\
\hline $\mathrm{Ka}^{+}$ & $\times$ & $\mathrm{Ha}^{+}$ & 18 & $38.3 \pm 1.20$ & & $98.1 \pm 0.67$ & & $94.8 \pm 1.16$ & & $77.9 \pm 0.90$ & \\
\hline $\mathrm{Ka}^{=}$ & $\times$ & $\mathrm{Ha}^{+}$ & 16 & $35.2 \pm 1.12$ & ns & $97.2 \pm 0.52$ & ns & $92.8 \pm 1.32$ & ns & $75.6 \pm 1.11$ & ns \\
\hline $\mathrm{Ka}^{+}$ & $x$ & $\mathrm{Mz}^{+}$ & 11 & $36.7 \pm 1.40$ & $* *$ & $97.8 \pm 0.49$ & $\mathrm{~ns}$ & $99.2 \pm 0.43$ & ns & $75.7 \pm 2.05$ & ns \\
\hline $\mathrm{Ka}=$ & $\times$ & $\mathrm{Mz}^{+}$ & 11 & $44.5 \pm 1.83$ & & $97.2 \pm 0.61$ & 110 & $99.2 \pm 0.35$ & & $78.8 \pm 2.46$ & \\
\hline $\mathrm{Ka}^{+}$ & $\times$ & $\mathrm{Ta}^{+}$ & 12 & $32.6 \pm 0.66$ & & $98.2 \pm 0.59$ & & $99.5 \pm 0.33$ & & $76.8 \pm 1.05$ & $\mathrm{~ns}$ \\
\hline $\mathrm{Ka}^{=}$ & $\times$ & $\mathrm{Ta}^{+}$ & 9 & $32.0 \pm 0.58$ & ns & $98.9 \pm 0.76$ & ns & $97.9 \pm 0.74$ & ns & $78.0 \pm 1.58$ & ns \\
\hline $\mathrm{Ka}^{+}$ & $\times$ & $\mathrm{Sh}^{+}$ & 11 & $40.2 \pm 1.08$ & $* * *$ & $97.4 \pm 0.77$ & ns & $97.5 \pm 0.32$ & ns & $72.1 \pm 2.34$ & $* *$ \\
\hline $\mathrm{Ka}^{=}$ & $\times$ & $\mathrm{Sh}^{+}$ & 11 & $30.1 \pm 0.96$ & & $98.5 \pm 0.51$ & & $97.8 \pm 0.68$ & & $82.1 \pm 1.65$ & \\
\hline $\mathrm{Ka}^{+}$ & $\times$ & $\mathrm{Su}^{+}$ & 13 & $34.8 \pm 2.01$ & & $96.6 \pm 0.92$ & & $97.8 \pm 0.61$ & & $82.8 \pm 0.95$ & \\
\hline $\mathrm{Ka}^{=}$ & $\times$ & $\mathrm{Su}^{+}$ & 11 & $33.9 \pm 1.40$ & ns & $95.7 \pm 1.15$ & ns & $98.0 \pm 0.49$ & ns & $83.5 \pm 1.26$ & ns \\
\hline $\mathrm{Ka}^{+}$ & $\times$ & $\mathrm{Mi}^{+}$ & 10 & $34.4 \pm 1.98$ & $* *$ & $96.5 \pm 1.11$ & nc & $92.6 \pm 0.82$ & $*$ & $84.4 \pm 1.11$ & \\
\hline $\mathrm{Ka}^{=}$ & $\times$ & $\mathrm{Mi}^{+}$ & 13 & $44.4 \pm 1.96$ & & $98.7 \pm 0.39$ & ns & $98.9 \pm 0.45$ & & $83.9 \pm 1.03$ & ns \\
\hline
\end{tabular}

aKa: Kanaya, Shizuoka; Ts: Tsukuba, Ibaraki; Ki: Kimitsu, Chiba; Ha: Haibara, Shizuoka; Mz: Miza, Kagoshima; Ta: Takeyano, Kagoshima; Sh: Shidoshi, Kagoshima; Su: Sumiyoshi, Kagoshima; Mi: Miyanoura, Kagoshima. ${ }^{b}$ Number of females tested. ${ }^{c}$ Means ( \pm SE) differ significantly at $P<0.001\left(^{* * *}\right), P<0.01\left(^{* *}\right)$ and $P<0.05(*)$; ns: not significantly different at $P>0.05$ (Mann-Whitney $U$-test).

Table 6 Combatibility of crosses between Wolbachia-infected Futtsu population $\left(\mathrm{Fu}^{+}\right)$and Wolbachia-uninfected Ami population $\left(\mathrm{Am}^{-}\right)$ in Tetranychus parakanzawai

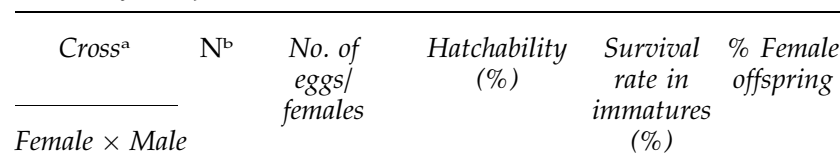

$\mathrm{Fu}^{+} \times \mathrm{Fu}^{+} \quad 15 \quad 37.5 \pm 1.44 \mathrm{ab} 94.4 \pm 0.75$ c $\quad 97.6 \pm 0.80 \quad 82.1 \pm 1.38$

$\mathrm{Fu}^{+} \times \mathrm{Am}^{-} 1234.8 \pm 2.25$ b $96.6 \pm 0.93$ bc $97.9 \pm 1.0183 .4 \pm 1.44$

$\mathrm{Am}^{-} \times \mathrm{Fu}^{+} 1537.7 \pm 1.87 \mathrm{ab} 98.0 \pm 0.58 \mathrm{ab} 97.6 \pm 1.46 \quad 81.9 \pm 1.22$

$\mathrm{Am}^{-} \times \mathrm{Am}^{-} 34 \quad 43.9 \pm 1.24$ a $99.2 \pm 0.37$ a $97.8 \pm 0.6682 .7 \pm 0.47$

$\begin{array}{llll}\chi^{2} \text {-value }^{\mathrm{c}} \quad 15.058^{* *} & 28.493^{* * *} & 2.846 \mathrm{~ns} & 1.996 \mathrm{~ns}\end{array}$

${ }^{a} \mathrm{Fu}^{+}$: Futtsu, Chiba; Am: Ami, Ibaraki. ${ }^{\mathrm{b} N u m b e r}$ of females tested cMeans $( \pm \mathrm{SE})$ differ significantly at $P<0.001(* * *)$ and $P<0.01(* *)$ (Kruskal-Wallis test); ns: not significant at $P>0.05$. Values in a column followed by different letters are significantly different at $P<0.05$ (Scheffé's test).

kanzawai populations, four T. pueraricola populations and two T. urticae populations). The wsp, $81 \mathrm{~F}$ and $691 \mathrm{R}$ primer pairs amplified 555-, 552- and 549-bp DNA fragments (not including the primer sequences). Phylo- genetic analyses of Wolbachia based on the wsp gene sequences indicated that all Wolbachia strains in spider mites from Japan (21 populations) and from two other regions belonged to supergroup B (Figure 2) (Werren et al, 1995b). All nine Wolbachia strains that possess the 555-bp size gene belonged to the Con subgroup and 10 Wolbachia strains of the 552-bp size gene were members of the Ori subgroup (see Zhou et al, 1998; van Meer et al, 1999). Two Wolbachia strains, which were found in O. gotohi and had the 549-bp size gene, formed a new and distinct group in the phylogenetic tree. This group was named the Epo subgroup (after Acraea eponina). The Wolbachia strains in the spider mites formed six clades within the B supergroup: three in the Con subgroup, two in the Ori subgroup and one in the Epo subgroup (Figure 2). Parsimony analysis also supported the six clades of Wolbachia (data not shown).

The CI-Wolbachia strains in the Sendai, Toyama and Hanayama populations of P. mori had identical ws $p$ gene sequences and were placed in the Ori subgroup. The wsp sequence was the same as the sequences in two populations of $T$. kanzawai and three populations of T. pueraricola. Thus, this wsp sequence was shared by Wolbachia from eight Japanese populations of P. mori, T. kanzawai and T. pueraricola. It is also identical to the 

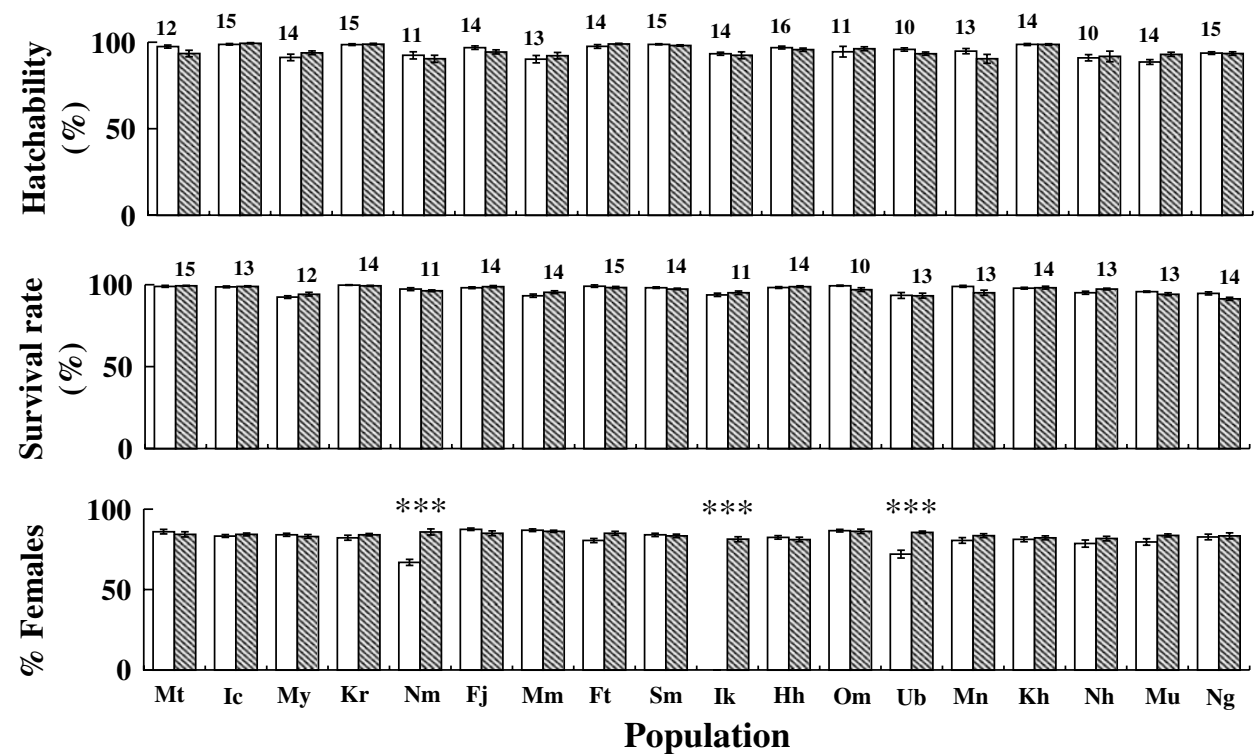

Figure 1 Hatchability, survival rate in immature stages and sex ratio (\% females) in crosses between the Wolbachia-free Ohta population and the Wolbachia-infected local populations in Tetranychus pueraricola. Open bars indicate crosses between females of each test populations and males of the Ohta population, and hatched bars indicate the reciprocal crosses. Numbers on the bars indicate the number of pairs tested. Vertical lines indicate the standard error. Mt: Matsuo, Iwate; Ic; Ichinoseki, Iwate; My: Matsuyama, Yamagata; Kr: Kiryu, Gunma; Nm: Namerikawa, Toyama; Fj: Fujioka, Tochigi; Mm: Matsumoto, Nagano; Ft: Futtsu, Chiba; Sm: Shimada, Shizuoka; Ik: Ikaruga, Nara; Hh: Higashi-Hiroshima, Hiroshima; Om: Onomichi, Hiroshima; Ub: Ube, Yamaguchi; Mn: Mononobe, Kohchi; Kh: Kahoku, Kohchi; Nh: Nishihara, Kumamoto; Mu: Miyanoura, Kagoshima; Ng: Nagata, Kagoshima.

Table 7 Compatibility of crosses between Wolbachia-infected $\left(\mathrm{Ya}^{+}\right)$ and tetracycline-treated $\left(\mathrm{Ya}^{=}\right)$colonies of Yasato population in Tetranychus urticae

\begin{tabular}{|c|c|c|c|c|c|c|c|}
\hline \multicolumn{3}{|c|}{ Cross $^{a}$} & \multirow[t]{2}{*}{$\mathrm{N}^{\mathrm{b}}$} & \multirow{2}{*}{$\begin{array}{l}\text { No. of } \\
\text { eggs/ } \\
\text { females }\end{array}$} & \multirow{2}{*}{$\begin{array}{l}\text { Hatchability } \\
\text { (\%) }\end{array}$} & \multirow{2}{*}{$\begin{array}{c}\text { Survival } \\
\text { rate in } \\
\text { immatures } \\
(\%)\end{array}$} & \multirow{2}{*}{$\begin{array}{l}\text { \% Female } \\
\text { offspring }\end{array}$} \\
\hline Female & $x$ & Male & & & & & \\
\hline $\mathrm{Ya}^{+}$ & $x$ & $\mathrm{Ya}^{+}$ & 13 & $53.3 \pm 1.33$ & $96.6 \pm 1.06$ & $97.8 \pm 0.81$ & $67.9 \pm 1.58$ \\
\hline $\mathrm{Ya}^{+}$ & $x$ & $\mathrm{Ya}^{=}$ & 15 & $50.0 \pm 1.77$ & $95.8 \pm 0.81$ & $96.7 \pm 1.34$ & $70.3 \pm 1$ \\
\hline $\mathrm{Ya}^{=}$ & $\times$ & $\mathrm{Ya}^{+}$ & 13 & $49.8 \pm 2.23$ & $97.4 \pm 0.36$ & $98.1 \pm 0.84$ & $72.6 \pm 1$ \\
\hline $\mathrm{Ya}^{=}$ & $\times$ & $\mathrm{Ya}^{=}$ & 11 & $51.5 \pm 2.09$ & $96.8 \pm 0.83$ & $98.0 \pm 1.26$ & $72.6 \pm 1$ \\
\hline \multicolumn{3}{|c|}{$\chi^{2}$-value } & & $2.468 \mathrm{~ns}$ & $1.237 \mathrm{~ns}$ & $0.961 \mathrm{~ns}$ & $5.220 \mathrm{~ns}$ \\
\hline
\end{tabular}

aYa: Yasato, Ibaraki. ${ }^{\mathrm{a}}$ Number of females tested. ${ }^{\mathrm{c}}$ Means $( \pm \mathrm{SE})$ are not significantly different at $P>0.05$ (Kruskal-Wallis test).

sequence of Wolbachia in T. urticae in the United States (AF217719), which has a length of more than $536 \mathrm{bp}$, and differs by one nucleotide from the sequence in the European population of T. urticae (AJ437288) (AF217719 is not shown in Figure 2 because of its shorter length). The wsp sequence of T. urticae (Yasato and Kitsuregawa populations) was identical to that of $T$. urticae from Europe (AF404766). The wsp sequences of mite Wolbachia in the Ori subgroup are similar. At most, the sequences in the Japanese, European and American populations differ from each other by three nucleotides.

\section{Discussion}

In our survey of 42 species and 362 populations of spider mites from Japan, the frequency of infected species was
$16.7 \%$ (seven of 42 species). For most species (36/42), we tested more than 10 individuals for Wolbachia infection. Similar frequencies of infection have been reported for other arthropods (eg Werren et al, 1995a (16.9\%); West et al, 1998 (21.7\%); Werren and Windsor, 2000 (19.3\%); Jiggins et al, $2001(16.7 \%))$. However, Breeuwer and Jacobs (1996) detected Wolbachia in six out of 16 species (37.5\%). Among mites of the genus Tetranychus, they detected Wolbachia in four out of 12 species (33.3\%). We also detected Wolbachia at a high rate $(40 \% ; 4 / 10)$ in the genus Tetranychus. Our data revealed that the infection rate in genera other than Tetranychus was low $(9.4 \% ; 3 /$ 32). Wolbachia was unequally distributed among the genera of the spider mites. No Wolbachia infection was found in Aponychus, Sasanychus, Yezonychus, Eotetranychus or Amphitetranychus, although the number of the test species in these genera is not sufficient to say that these genera are Wolbachia free. Unequal distributions were also observed within a single genus. For example, we did not find Wolbachia in P. citri or P. osmanthi, even though 72 populations of the former and 44 populations of the latter were tested. Only one species of Panonychus, P. mori, was infected with Wolbachia.

The phylogenetic analysis of wsp genes revealed that Wolbachia in the spider mites in Japan belong to the subgroups Ori, Con and Epo in the supergroup B (Figure 2). The Ori and Con subgroups were first proposed by Zhou et al (1998) based on the wsp gene phylogeny. Zhou et al (1998) proposed that members of any subgroup should have a similarity in the wsp sequence greater than $97.5 \%$. Therefore, we now propose a new subgroup, the Epo subgroup, named after the host species Acraea eponina (accession number AJ271194), which was the first member of this subgroup to be deposited in the database. The Wolbachia strains in 


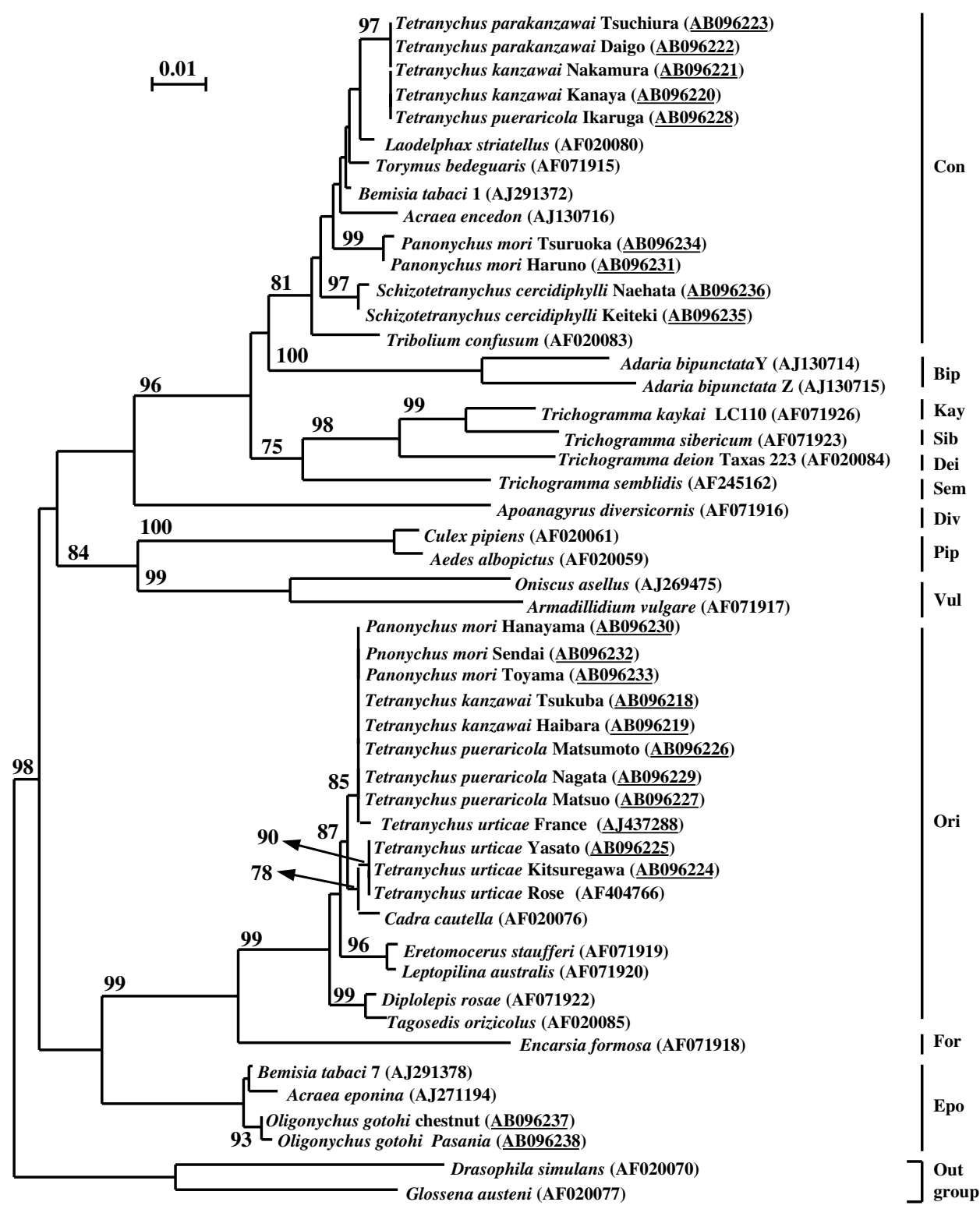

Figure 2 Phylogenetic tree based on wsp sequences of Wolbachia, constructed by a neighbor-joining procedure with Clustal X. Accession numbers with underlines indicate Wolbachia strains of the spider mites examined in this study. Wolbachia strains are indicated by the host name. DNA database accession numbers are shown after the host name in parentheses. Numbers on the nodes indicate bootstrap percent confidence values (more than 70). The tree, restricted to the B supergroup of Wolbachia, was rooted from two outgroups: Wolbachia from Glossina austeni (AF020077) and Drosophila simulans (Riverside) (AF020070).

O. gotohi belong to the subgroup Epo, and are distantly related to other Wolbachia strains in spider mites. Wolbachia in S. cercidiphylli belongs to the subgroup Con, and the strains in T. urticae including the European populations belong to the subgroup Ori. Wolbachia in the other four species among the populations were separated into the subgroups Con and Ori. These results suggest that Wolbachia in the spider mites originated from a few or several ancestral strains and have been inherited for many generations of the spider mites. As has been pointed out by many authors (eg Werren et al, 1995b; van Meer et al, 1999), acquisition of Wolbachia in the spider mites appears to be due to horizontal infection, because the phylogeny of Wolbachia is not concordant with that of the host species, and the same mite species had different
Wolbachia strains. Identical nucleotide sequences of wsp genes were detected in eight populations from three species in the subgroup Ori, suggesting recent horizontal transmission of Wolbachia among the spider mites. As was pointed out by Jiggins et al (2002), Wolbachia are more likely to move horizontally within the host groups than between distantly related hosts. Horizontal transmission is considered to be caused by parasites or parasitoids (Heath et al, 1999; Huigens et al, 2000; Noda et al, 2001b), but it is unknown how the bacteria have spread among the spider mites.

An important result of the phylogenetic tree is that the same species possess the same strain or a very close strain of Wolbachia despite the location of the host mites. Closely related strains of Wolbachia were found in 
T. urticae of the European and Japanese populations. Based on the wsp gene sequences, the same Wolbachia strain was detected in the Sendai, Toyama and Hanayama populations of $P$. mori. These observations indicate that different species of spider mites are associated with specific strains of Wolbachia. One possible explanation of this phenomenon is that the relationship between the mites and Wolbachia is old and Wolbachia have been inherited from many generations in the same species. This means Wolbachia have spread geographically through the parasite population. Another possible explanation is that the infection comes from parasites of spider mites, because Wolbachia-infected populations distribute patchily and do not show any continuous distribution even on cultivated crops, which is different from the continuous distribution caused by spreading of Drosophila simulans (Turelli and Hoffmann, 1991) or Laodelphax striatellus (Noda et al, 2001b). That is, a parasite that is specific to a given species of spider mite might carry a specific strain of Wolbachia. However, the latter explanation needs further evidence that similar parasites with the same Wolbachia strain attack the spider mites in Japan and Europe. Wolbachia is distributed among the spider mites by horizontal and vertical transmissions, although it is hard to fully explain how this transmission occurs.

Cytoplasmic incompatibility in spider mites was first reported in T. urticae (Breeuwer, 1997). However, Japanese T. urticae or T. kanzawai did not show cytoplasmic incompatibility (Gomi et al, 1997; Gotoh et al, 1999a, b). These two species shared an identical wsp sequence with $P$. mori, which showed cytoplasmic incompatibility. Although cytoplasmic incompatibility may require a certain density of Wolbachia rather than just the presence of Wolbachia (Noda et al, 2001a), our preliminary real-time PCR studies did not support the different density effect of Wolbachia between P. mori and Tetranychus species. There are two possible explanations for the phenomenon that Wolbachia of indistinguishable or the closely related gene sequences show different phenotypes. One is that the expression of cytoplasmic incompatibility depends on the mite strains that are hosts of Wolbachia. Another one is that Wolbachia have recently changed in phenotype, which is suggested by Jiggins et al (2002). This phenotypic change in Wolbachia may support the difference in cytoplasmic incompatibility phenotype of T. urticae between Europe and Japan.

\section{Acknowledgements}

We thank K Iwadate and S Kawai of Ibaraki University for their technical assistance. This work was supported in part by Grants-in-Aid for Scientific Research (nos. 09660040 and 12460019) from the Ministry of Education, Science, Sports and Culture of Japan.

\section{References}

Bandi C, Anderson TJC, Genchi C, Blaxter ML (1998). Phylogeny of Wolbachia-like bacteria in filarial nematodes. Proc R Soc Lond B 265: 2407-2413.

Bouchon D, Rigaud T, Juchault P (1998). Evidence for widespread Wolbachia infection in isopod crustaceans: molecular identification and host feminization. Proc $R$ Soc Lond B 265: 1081-1090.
Breeuwer JAJ (1997). Wolbachia and cytoplasmic incompatibility in the spider mites Tetranychus urticae and T. turkestani. Heredity 79: 41-47.

Breeuwer JAJ, Jacobs G (1996). Wolbachia: intracellular manipulators of mite reproduction. Exp Appl Acarol 20: 421-434.

Ehara S (1999). Revision of the spider mite family Tetranychidae of Japan (Acari, Prostigmata). Species Diversity 4: 63-141.

Ehara S, Ohashi K (2002). A new species of Tetranychus (Acari: Tetranychidae) from the Kinki District, Japan. Acta Arachnol 51: 19-22.

Ehara S, Yamaguchi T (2001). Discovery of Tetranychus neocaledonicus Andre (Acari, Tetranychidae) from AmamiOhshima Island, Japan. Plant Protect 55: 268-272 (in Japanese)

Gomi K, Gotoh T, Noda H (1997). Wolbachia having no effect on reproductive incompatibility in Tetranychus kanzawai Kishida (Acari: Tetranychidae). Appl Entomol Zool 32: 485-490.

Gotoh T, Gomi K, Nagata T (1999a). Incompatibility and host plant differences among populations of Tetranychus kanzawai Kishida (Acari: Tetranychidae). Appl Entomol Zool 34: $551-561$.

Gotoh T, Oku H, Moriya K, Odawara M (1995). Nucleuscytoplasmic interactions causing reproductive incompatibility between two populations of Tetranychus quercivorus Ehara et Gotoh (Acari: Tetranychidae). Heredity 74: 405-414.

Gotoh T, Sugasawa J, Nagata T (1999b). Reproductive compatibility of the two-spotted spider mite (Tetranychus urticae) infected with Wolbachia. Entomol Sci 2: 289-295.

Heath BD, Butcher RDJ, Whitfield WGF, Hubbard SF (1999). Horizontal transfer of Wolbachia between phylogenetically distant insect species by a naturally occurring mechanism. Curr Biol 9: 313-316.

Holden PR, Brookfield JFY, Jones P (1993). Cloning and characterization of an ftsZ homologue from a bacterial symbiont of Drosophila melanogaster. Mol Gen Genet 240: 213-220.

Huigens ME, Luck RF, Klaassen RHG, Maas MFPM, Timmerman MJTN (2000). Infectious parthenogenesis. Nature 405: 178-179.

Jeyaprakash A, Hoy MA (2000). Long PCR improves Wolbachia DNA amplification: wsp sequences found in $76 \%$ of sixtythree arthropod species. Insect Mol Biol 9: 393-405.

Jiggins FG, Bentley JK, Majerus MEN, Hurst GDD (2001). How many species are infected with Wolbachia? Cryptic sex ratio distorters revealed to be common by intensive sampling. Proc $R$ Soc Lond B 268: 1123-1126.

Jiggins FG, Bentley JK, Majerus MEN, Hurst GDD (2002). Recent changes in phenotype and patterns of host specialization in Wolbachia bacteria. Mol Ecol 11: 1275-1283.

Johanowicz DL, Hoy MA (1996). Wolbachia in a predator-prey system: 16S ribosomal DNA analysis of two phytoseiids (Acari: Phytoseiidae) and their prey. Ann Entomol Soc Am 89: 435-441.

Johanowicz DL, Hoy MA (1998). Experimental induction and termination of non-reciprocal incompatibilities in a parahaploid mite. Entomol Exp Appl 87: 51-58.

Johanowicz DL, Hoy MA (1999). Wolbachia infection dynamics in experimental laboratory populations of Metaseiulus occidentalis. Entomol Exp Appl 93: 259-268.

Kittayapong P, Baisley KJ, Baimai V, O'Neill SL (2000). Distribution and diversity of Wolbachia infections in southeast Asian mosquitoes (Diptera: Culicidae). J Med Entomol 37: 340-345.

Lo N, Casiraghi M, Salati E, Bazzocchi C, Bandi C (2002). How many Wolbachia supergroups exist? Mol Biol Evol 19: 341-346.

Noda H, Koizumi Y, Zhang Q, Deng K (2001a) Infection density of Wolbachia and incompatibility level in two planthopper species, Laodelphax striatellus and Sogatella furcifera. Insect Biochem Mol Biol 31: 727-737.

Noda H, Miyoshi T, Zhang Q, Watanabe K, Deng K, Hoshizaki S (2001b). Wolbachia infection shared among planthoppers 
(Homoptera: Delphacidae) and their endoparasite (Strepsiptera: Elenchidae): a probable case of interspecies transmission. Mol Ecol 10: 2101-2106.

O'Neill SL, Giordano R, Colbert AME, Karr TL, Robertson HM (1992). 16S rRNA phylogenetic analysis of the bacterial endosymbionts associated with cytoplasmic incompatibility in insects. Proc Natl Acad Sci USA 89: 2699-2702.

O'Neill SL, Hoffmann AA, Werren JH (eds) (1997). Influential Passengers: Inherited Microorganisms and Arthropod Reproduction. Oxford University Press: New York. 214pp.

Perrot-Minnot M-J, Norton RA (1997). Obligate thelytoky in oribatid mites: no evidence for Wolbachia inducement. Can Entomol 129: 691-698.

Schilthuizen M, Gittenberger E (1998). Screening mollusks for Wolbachia infection. I Invert Pathol 71: 268-270.

Stouthamer R, Breeuwer JAJ, Hurst GDD (1999). Wolbachia pipientis: microbial manipulator of arthropod reproduction. Annu Rev Microbiol 53: 71-102.

Swofford DL (1999). PAUP*: Phylogenetic Analysis Using Parsimony, v. 4.0b2. Sinauer Associates: Sunderland, MA.

Thompson JD, Gibson TJ, Plewniak F, Jeanmougin F, Higgins DG (1997). The CLUSTAL X windows interface: flexible strategies for multiple sequence alignment aided by quality analysis tool. Nucleic Acids Res 25: 4876-4882.

Tsagkarakou A, Guillemaud T, Rousset F, Navajas M (1996). Molecular identification of a Wolbachia endosymbiont in a Tetranychus urticae strain (Acari: Tetranychidae). Insect Mol Biol 5: 217-221.

Turelli M, Hoffmann AA (1991). Rapid spread of an inherited incompatibility factor in California Drosophila. Nature 353 440-442.
Vala F, Breeuwer JAJ, Sabelis MW (2000). Wolbachia-induced 'hybrid breakdown' in the two-spotted spider mite Tetranychus urticae Koch. Proc R Soc Lond B 267: 1931-1937.

Vandekerchove TMT, Watteyne S, Willems A, Swings JG, Mertens J, Gillis M (1999). Phylogenetic analysis of the 16S rDNA of the cytoplasmic bacterium Wolbachia from the novel host Folsomia candida (Hexapoda, Collembola) and its implications for wolbachial taxonomy. FEMS Microbiol Lett 180: 279-286.

Van Meer MMM, Witteveldt J, Stouthamer R (1999). Phylogeny of the arthropod endosymbiont Wolbachia base on the wsp gene. Insect Mol Biol 8: 399-408.

Wenseleers T, Ito F, van Borm S, Huybrechts R, Volckaert F (1998). Widespread occurrence of the micro-organism Wolbachia in ants. Proc R Soc Lond B 265: 1447-1452.

Werren JH, Windsor DM (2000). Wolbachia infection frequencies in insects: evidence of a global equilibrium? Proc $R$ Soc Lond $B$ 267: 1277-1285.

Werren JH, Windsor DM, Guo LR (1995a). Distribution of Wolbachia among neotropical arthropods. Proc $R$ Soc Lond $B$ 262: 197-204.

Werren JH, Zhang W, Guo LR (1995b). Evolution and phylogeny of Wolbachia: reproductive parasites of arthropods. Proc R Soc Lond B 261: 55-63.

West SA, Cook JM, Werren JH, Godfray HCJ (1998). Wolbachia in two insect host-parasitoid communities. Mol Ecol 7: 1457-1465.

Zhou WG, Rousset F, O'Neill SL (1998). Phylogeny and PCRbased classification of Wolbachia strains using wsp gene sequences. Proc R Soc Lond B 265: 509-515. 